\title{
Safety and tolerability of controlled-release oxycodone on postoperative pain in patients submitted to the oncologic head and neck surgery
}

\section{Segurança e tolerabilidade da oxicodona de liberação controlada em dores pós- operatórias em pacientes submetidos à operações oncológicas de cabeça e pescoço}

\author{
Ismar lima Cavalcanti ${ }^{1}$; Ana Claudia Geraldino de Carvalho²; Mariana Gonçalves Musauer ${ }^{2}$; Vanessa Salóes Rodrigues²; \\ Renato Nobre Migon²; Nubia Verçosa Figueiredo ${ }^{3}$; Luis Antonio Vane ${ }^{4}$
}

\begin{abstract}
A B S T R A C T
Objective: To evaluate the safety and tolerability of controlled-release oxycodone in the treatment of postoperative pain of head and neck oncologic resections. Methods: We conducted a prospective, observational and open study, with 83 patients with moderate to severe pain after head and neck oncological operations. All patients received general anesthesia with propofol, fentanyl and sevoflurane. Postoperatively, should they have moderate or severe pain, we began controlled-release oxycodone 20 $\mathrm{mg} \mathrm{12/12} \mathrm{b.i.d} \mathrm{on} \mathrm{the} \mathrm{first} \mathrm{day} \mathrm{and} 10 \mathrm{mg}$ b.i.d. on the second. We assessed the frequency and intensity of adverse effects, the intensity of postoperative pain by a verbal numeric scale and the use of rescue analgesia from 12 hours after administration of the drug and between 7 and 13 days after the last oxycodone dose. Results: The most common adverse events were nausea, vomiting, dizziness, pruritus, insomnia, constipation and urinary retention, most mild. No serious adverse events occurred. In less than 12 hours after the use of oxycodone, there was a significant decrease in the intensity of postoperative pain, which remained until the end of the study. The rescue medication was requested at a higher frequency when the opioid dose was reduced, or after its suspension. Conclusion: Controlled release oxycodone showed to be safe and well tolerated and caused a significant decrease in postoperative pain.
\end{abstract}

Key words: Surgical procedures, operative. Pain, postoperative. Analgesia. Oxycodone. Clinical trial.

\section{INTRODUCTION}

C ancer is an obvious problem of global public health. The World Health Organization (WHO) estimates that, by the year 2030, one can expect 27 million cancer cases and 17 million cancer deaths. In Brazil, it was estimated that 518,510 new cases of cancer occurred in $2012^{1}$. In this context, there is growing demand for operative chemotherapy and, as a result, the search for better management of postoperative pain, aiming not only at a better surgical outcome, but also at the reduction and prevention of chronic pain.

Oxycodone is a semi-synthetic opioid analgesic that is a $\mathrm{m}(\mathrm{mu})$ receptor agonist and a $\mathrm{k}$ (kappa) receptor partial agonist, which may make it a drug with a special indication for surgical treatment in cases where there is involvement of both the somatic and visceral components in the pain genesis ${ }^{2}$. The presentation in the form of controlled release may be beneficial because it reduces the number of administrations, making the pain control more predictable and effective. Parenterally, oxycodone has the same analgesic efficacy for somatic pain as presented by morphine, but with faster onset of action and less potential for histamine release.

In Brazil, some opioids are often used for the treatment of postoperative pain. However, oxycodone is barely used, whether in the presentation of immediate release or in the controlled one. In addition, there are no clinical studies in this type of surgical scenario, especially in head and neck cancer.

The hypothesis of this study is that the controlled release oxycodone can be safe and well tolerated for the control of postoperative pain in head and neck operations for the treatment of cancer. Therefore, the objective of this research was to evaluate the safety and tolerability of controlled-release oxycodone in the pain treatment of postoperative oncologic resection of the head and neck.

1. Department of General and Specialized Surgery, Fluminense Federal University - UFF; 2. José Alencar Gomes da Silva National Cancer Institute - INCA; 3. Department of Surgery, Faculty of Medicine, Federal University of Rio de Janeiro - UFRJ; 4. Department of Anesthesiology, School of Medicine, Julio de Mesquita Filho São Paulo State University - UNESP. 


\section{METHODS}

This phase IV, observational, prospective, open clinical trial was approved by the Ethics in Research Committee of the José Alencar Gomes da Silva National Cancer Institute - INCA (10/2010) and was recorded in ClinicalTrials - NCT01834898. The Informed Consent Form (ICF) was signed by all patients.

We included 83 patients of both genders, aged between 18 and 70 years, ASA 2 and 3, who had postoperative pain ranging from moderate to severe after medium and large oncological elective operations of the head and neck, and able to swallow whole pills in the immediate postoperative period.

We excluded pregnant women, infants and patients allergic to oxycodone or other opioids, previous gastric resection, colostomists, asthmatics with severe organ dysfunction, with history or suspected paralytic ileus, with reports of psychiatric illness, severe respiratory disease, those who were receiving some opioid analgesics at baseline, with a history of alcohol or illicit drugs abuse or who had, in plasma, glutamic oxaloacetic transaminase (AST) above $48 \mathrm{U} / \mathrm{I}$ (men) and $40 \mathrm{U} / \mathrm{l}$ (women) and/or glutamic pyruvic transaminase (ALT) above $53 \mathrm{U} / \mathrm{I}$ (men) and $40 \mathrm{U} / \mathrm{I}$ (women) and creatinine above $1.7 \mathrm{mg} / \mathrm{dl}$ and/or urea above $65 \mathrm{mg} /$ dl.

All patients were preoperatively evaluated on the week prior to the operation (visit 1), when the ICF was signed, the pre-anesthetic evaluation was carried out and the pain intensity evaluated through the Verbal Numerical Scale (VNS) ${ }^{3}$, which classifies events in 0 as absence, 1-3 as mild, 4-6 as moderates, and those between 7 and 10 as severe; we also collected blood for laboratory tests: complete blood count, â-hCG (women) AST, ALT, urea and creatinine.

Patients were treated with midazolam $7.5 \mathrm{mg}$ in the previous night and $15 \mathrm{mg}$ in the morning of the procedure. All patients received general anesthesia. Induction consisted of $2 \mathrm{mg} \mathrm{kg}^{-1}$ propofol, $2 \mathrm{mg} . \mathrm{kg}^{1}$ lidocaine, fentanyl 3-5 microg. $\mathrm{kg}^{-1}$, esmolol $2 \mathrm{mg} \cdot \mathrm{kg}^{-1}$ and cisatracurium $0,15 \mathrm{mg} \cdot \mathrm{kg}^{-1}$, intravenously. Tracheal intubation followed five minutes of ventilation by face mask with $\mathrm{O}_{2}$ and sevoflurane. Maintenance of anesthesia was induced with sevoflurane plus continuous intravenous dexmedetomidine at a dose 0.2 to $0.7 \mathrm{ig} . \mathrm{kg} \cdot \mathrm{min}^{-1}$ (discontinued one hour before the end of the operation).

Postoperatively (visit 2), when they had moderate or severe pain (NVSe 3 ), controlled-release oxycodone was initiated at $20 \mathrm{mg}$ b.i.d. on the first day and $10 \mathrm{mg}$ b.i.d. on the second day. We assessed the frequency and intensity of adverse effects, the intensity of postoperative pain and the use of analgesic rescue medication every 12 hours after the drug administration (visits 3 to 6) and between 7 and 13 days after the last dose (visit 7). During visit 7, we also collected blood to perform the same tests listed in visit 1, except â hCG (women), the investigator noted his/her opinion on the quality of treatment and the study was terminated.

To rescue medication we used non-opioid analgesics such as parecetamol, dipyrone, tenoxicam or ketoprofen, only after the first postoperative administration of controlled-release oxycodone. In the visits 3-7 we recorded the rescue analgesia and frequency of administration.

\section{Sample size and statistical analysis}

When considering the occurrence of nausea of $25 \%$ as a security parameter assessed by literature data, the number of patients necessary would be 72 (to obtain a precision of $10 \%$ in a $95 \%$ confidence interval). Taking possible losses into consideration, we included 83 patients. The normality study of the variable age was done with the Kolgomorov-Smirnov test. We used the McNemar test for comparisons of paired proportions of adverse events (visits 4, 5, 6 and 7 with respect to visit 3) ( $p<0.05=$ significant $)$ and the Q Cochran test to determine the overall value of $p$ in the analysis of adverse effects. We used the Wilcoxon test for multiple comparisons of the intensity distributions of pain from Visit 2 to Visit 7, according to the period of analgesic (with or without controlled release oxycodone). Other data were presented by frequency.

\section{RESULTS}

\section{Study population}

Of the 83 patients enrolled, 14 were excluded from the analysis of tolerance and 16 from the analysis of pain intensity due to deviations in the protocol. Patient characteristics, assessed at visit 1 , are shown in table 1

The types and frequency of operations in the patients included in the study were: total thyroidectomy $(45.83 \%)$, partial thyroidectomy $(8.33 \%)$, total neck dissection (19.44\%), operations in the eye $(5,56 \%)$, parotidectomy $(9.72 \%)$, exploratory cervicotomy $(4.17 \%)$, cervical tumor resection (2.78\%), resection of skin tumors (2.78\%) and resection of maxillo-ethmoid tumors (2.78\%).

\section{Safety and tolerability assessment}

Sixty-nine patients were evaluated for safety and tolerability. The most common adverse effects which were possibly related to medication were: nausea, vomiting, dizziness, pruritus, insomnia, constipation and urinary retention (Table 2 ).

Most adverse events were mild and, in the course of the study, there were no adverse events of severe intensity (Table 3).

During the visits 3 and 4, most of the adverse effects were possibly related to oxycodone, and at visits 5, 6 and 7, not related to the drug (Table 4). 
Table 1 - Characteristics of the patients.

\begin{tabular}{|c|c|c|}
\hline & Mean (Sd) & Minimum-maximum \\
\hline Age & $(11.1)$ & -69 \\
\hline Weight (kg) & (15.5) & $40-112$ \\
\hline Height (m) & $(0.08)$ & $1.42-1.80$ \\
\hline BMI $\left(\mathrm{kg} / \mathrm{m}^{2}\right)$ & 27.24 & $16.2-42.9$ \\
\hline Gender & n (\%) & \\
\hline Male & $22 \quad(26.5)$ & \\
\hline Female & $61 \quad(73.5)$ & \\
\hline ASA Classification & n (\%) & \\
\hline । & $40(48.19)$ & \\
\hline ॥ & $36(43.37)$ & \\
\hline III & $7 \quad(8.43)$ & \\
\hline
\end{tabular}

Study of the normality of the variable age with Kolgomorov-Smirnov test.

Table 2 - Frequency of adverse effects at visits 3 through 7.

\begin{tabular}{lccccc}
\hline Adverse eventsn (\%) & $\begin{array}{r}\text { Visit 3 } \\
(n=72)\end{array}$ & $\begin{array}{r}\text { Visit 4 } \\
(\mathrm{n}=72)\end{array}$ & $\begin{array}{c}\text { Visit 5 } \\
(\mathrm{n}=72)\end{array}$ & $\begin{array}{r}\text { Visit 6 } \\
(\mathrm{n}=72)\end{array}$ & $\begin{array}{r}\text { Visit 7 } \\
(\mathrm{n}=69)\end{array}$ \\
\hline Nausea & $14(19.44)$ & $11(15.28)$ & $4(5.56)$ & $1(1.39)$ & $1(1.45)$ \\
Vomiting & $8(11.11)$ & $9(12.50)$ & $1(1.39)$ & $1(1.39)$ & - \\
Dizziness & $2(2.78)$ & $3(4.17)$ & $1(1.39)$ & - & $3(4.35)$ \\
Pruritus & $2(2.78)$ & $1(1.39)$ & - & - & - \\
Insomnia & $2(2.78)$ & - & - & - & - \\
Constipation & - & - & $3(4.17)$ & - & $3(4.35)$ \\
Urinary retention & $1(1.39)$ & - & - & - & - \\
Other * & $1(1.39)$ & $9(12.50)$ & $15(20.28)$ & $9(12.50)$ & $6(8.69)$ \\
Total & $30(41.67)$ & $33(45.83)$ & $24(33.33)$ & $11(15.28)$ & $13(18.84)$ \\
\hline
\end{tabular}

* Other: paresthesia in the ear, face, limbs and hands; facial flushing; headache; epigastralgia; odynophagia; burning sensation in the nose; cramps; neck pain; hiccups; fever; facial discomfort; shoulder pain and increase AST and/or ALT.

There were significant differences in the evolution of the proportions of adverse events since visit 3 till visit 7 (Table 5).

Adverse events decreased from visit 4 on, with significant differences after visit 6 . In visits 6 and 7 there were several patients who experienced adverse events not related to the study medication, such as shoulder pain, malaise on the cheek, neck pain, among others, which still favors the study medication, noting that no adverse events is directly related to controlled-release oxycodone.

\section{Analgesia Assessment}

For analysis of analgesia we used the data on the pain intensity through the numerical scale, from 67 patients since visit 2 (after the operation) till visit 7 (Table $6)$.

There was a highly significant reduction in pain intensity between visits 2 and $3(p<0.001)$. This decrease was maintained until the end of the study, demonstrating the stability of analgesia with the doses used. Furthermore, there was an increase in the proportion of patients without

Table 3 - Frequency of the intensity of the adverse effects of visits 3 through 7.

\begin{tabular}{lccrrr}
\hline Intensityn (\%) & $\begin{array}{l}\text { Visit 3 } \\
(n=72)\end{array}$ & $\begin{array}{l}\text { Visit 4 } \\
(n=72)\end{array}$ & $\begin{array}{r}\text { Visit 5 } \\
(n=72)\end{array}$ & $\begin{array}{r}\text { Visit 6 } \\
(n=72)\end{array}$ & $\begin{array}{r}\text { Visit 7 } \\
(n=69)\end{array}$ \\
\hline Mild & $20(66.67)$ & $23(69.70)$ & $15(62.50)$ & $8(72.72)$ & $9(69.23)$ \\
Moderate & $10(33.33)$ & $10(30.30)$ & $9(37.50)$ & $3(27.27)$ & $4(30.77)$ \\
\hline
\end{tabular}

Mild intensity: 1-3 in the Numerical Verbal Scale (EVN).

Moderate intensity: 4-6 in the EVN. 
Table 4 - Frequency of the relation of adverse effects with oxycodone in visits 3 through 7

\begin{tabular}{lccccc}
\hline $\begin{array}{l}\text { Relationship with } \\
\text { medication } \mathrm{n} \mathrm{( \% )}\end{array}$ & $\begin{array}{l}\text { Visit 3 } \\
(\mathrm{n}=72)\end{array}$ & $\begin{array}{l}\text { Visit 4 } \\
(\mathrm{n}=72)\end{array}$ & $\begin{array}{l}\text { Visit 5 } \\
(\mathrm{n}=72)\end{array}$ & $\begin{array}{l}\text { Visit 6 } \\
(\mathrm{n}=72)\end{array}$ & $\begin{array}{c}\text { Visit 7 } \\
(\mathrm{n}=69)\end{array}$ \\
\hline Unrelated & $3(10)$ & $2(69.70)$ & $14(58.33)$ & $9(81.82)$ & $6(46.15)$ \\
Possibly related & $27(90)$ & $31(30.30)$ & $10(41.67)$ & $2(18.18)$ & $7(53.85)$ \\
\hline
\end{tabular}

Table 5 - Comparisons of the frequencies of adverse events of visits 4, 5, 6 and 7 with visit 3 .

\begin{tabular}{|c|c|c|c|c|c|c|c|c|}
\hline \multirow{3}{*}{$\begin{array}{l}\text { Visit } 3 \\
\text { (after surgery) } \\
\text { overall } p \text {-value }<0.001^{* * * *}\end{array}$} & \multicolumn{2}{|c|}{ Visit 4} & \multicolumn{2}{|c|}{ Visit 5} & \multicolumn{3}{|c|}{ Visit 6} & \multirow{2}{*}{$\frac{\text { Visit } 7}{(31.88 \%) \text { vs }}$} \\
\hline & 22 & (31.88\%) vs & 22 & (31.88\%) vs & 22 & (31.88\%) vs & 22 & \\
\hline & 26 & (37.68\%) & 19 & $(27.54 \%)$ & 7 & $(10.14 \%)$ & 13 & (18.84\%) \\
\hline$p$ value*** & 0.503 & & 0.711 & & $0.003 *$ & & $0.093 * *$ & \\
\hline
\end{tabular}

* Five of the patients showed no adverse events related to the medication at visit 6 .

** Six of the patients showed no adverse events related to the medication at visit 7.

$* * *$ McNemar test for comparison of paired proportions.

$* * * *$ Cochran $Q$ test.

pain during visits. During the analgesia period, the proportions of patients with moderate to severe pain decreased, while the percentages of patients with mild pain or no pain increased (Figure 1).

\section{Use of rescue medication}

The most widely used rescue medication was dipyrone, followed by paracetamol. Only two patients used tenoxican and one patient made use of ketoprofen (Table 7).

\section{Researcher perception of the quality of treatment with oxycodone}

The perception about the analgesic treatment with controlled-release oxycodone was excellent for $68.1 \%$ and good for $31.9 \%$ of researchers.

\section{DISCUSSION}

Oxycodone is a semisynthetic opioid analgesic. The opioids, including oxycodone, act primarily in the cen- tral ì receptors. $k$ receptors on peripheral nerves may play an important role in the antinociception of the visceral pain system ${ }^{4,5}$. Although there is no consensus in the literature 6 , it has been suggested that oxycodone, besides acting on ì receptors, also acts on $\mathrm{k}$ receptors, partially responsible for the antinociceptive effects 7,8 . A study in healthy

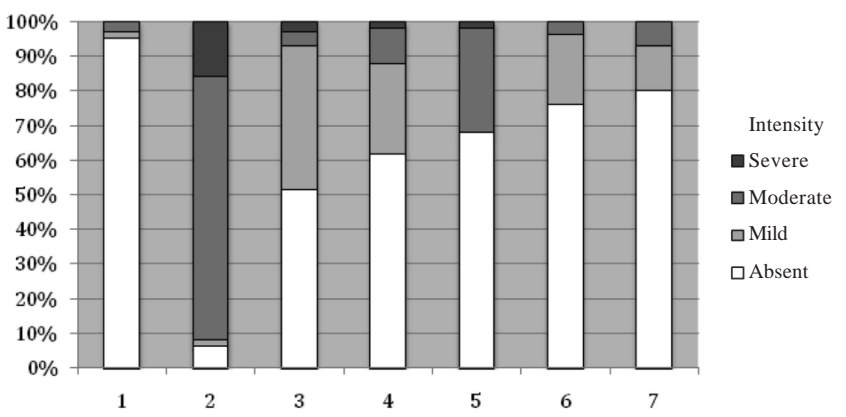

Figure 1 - Distribution of proportions of pain intensity at Visits 1 through $7(n=67)$.

Pain intensity through the Verbal Numerical Scale: Absent =0; Mild 13; Moderate: 4-6; and Severe: 7-10.

Table 6 - Multiple comparisons of pain intensity distributions of visits 2 through 7 ( $n=67)$, according to the period of analgesia (with or without controlled-release oxycodone).

\begin{tabular}{lcc}
\hline Treatment with controlled-release oxycodone & Visit & p-value \\
\hline Yes & 2 vs. 3 & $<0.001$ \\
Yes & 3 vs. 4 & 0.329 \\
Yes & 4 vs. 5 & 0.022 \\
Yes & 5 vs. 6 & 0.063 \\
No & 6 vs. 7 & 0.820 \\
\hline
\end{tabular}

* Wilcoxon test. 
Table 7 - Type of analgesic and frequency of use of rescue medication (visits 3 through 7).

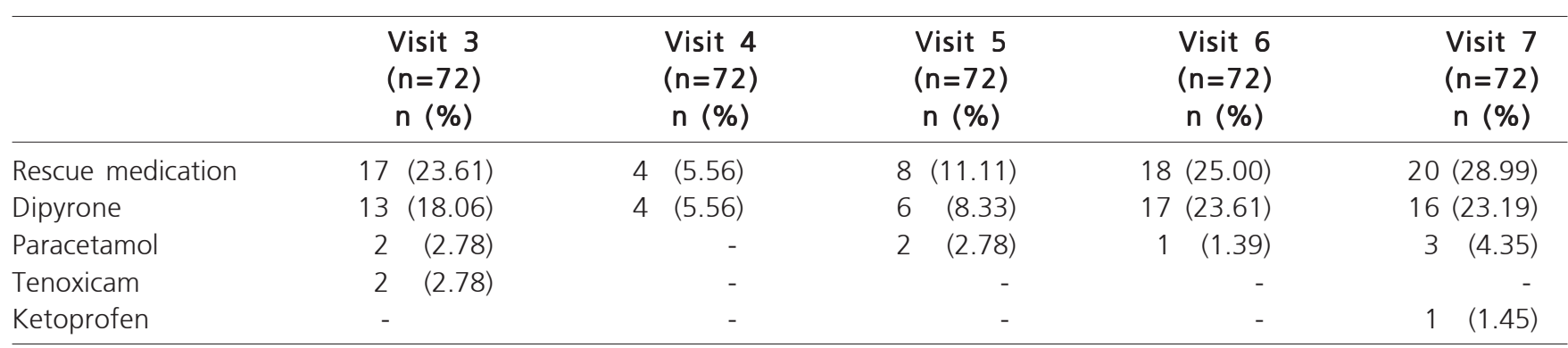

* Note: one patient received dipyrone for fever at visit 6, not for pain.

volunteers using mechanical, thermal and electrical painful tests in the skin, muscles, and viscera showed that both morphine and oxycodone decreased the pain in the skin and muscles, while the analgesic effect of oxycodone was superior to morphine in the pain of visceral origin ${ }^{2}$. There is also evidence that oxycodone is more effective for the pain caused by pancreatitis ${ }^{9}$.

The visceral component of postoperative pain is more difficult to treat than the somatic one. This may suggest that oxycodone is well indicated to treat postoperative pain in surgical oncology, where a visceral component plays an invariable role in the genesis of pain. Oncologic resections of the head and neck are of particular interest, since postoperative pain suffers interference from movements of the neck and swallowing, which can exacerbate the pain and result in failure of the analgesics treatment. Controlled-release oxycodone may be an important drug option for the treatment of acute refractory and frequent episodes of chronic neck pain in patients with response failure to conservative non-opioid treatment ${ }^{10}$.

The recent interest for oxycodone is based on its pharmacokinetic and pharmacodynamic properties, especially on the central nervous system. Moreover, the relatively high bioavailability allows an easy change of the drug formulation during the course of treatment. Oxycodone is highly effective and well tolerated in different operative procedures and patient groups ${ }^{11}$.

The indication of oral oxycodone for the treatment of postoperative pain, as proposed in this study, may be explained by its higher bioavailability when compared with morphine. The oral bioavailability of oxycodone $(>60 \%)$ is approximately twice that of morphine (20-25\%); This explains the fact that the relative potency of oral oxycodone is approximately twice as that of oral morphine ${ }^{12}$. Oxycodone is primarily metabolized by $\mathrm{N}$ demethylation (40\%) to noroxycodone and only to some extent by O-demethylation (11\%) to oxymorphone and a and b-oxymorfol and 6-keto reduction (8\%) in a and boxycodol ${ }^{13}$. Hepatic enzymes P450 2D6 (CYP 2D6) act as catalysts when oxycodone and oxymorphone are metabolised in noroxycodone noroxymorphone. A weak CYP 2D6 enzyme activity was observed in $5-10 \%$ of the
Caucasian population. The time to peak plasma concentration is 1.3 hours after oral intake of immediaterelease oxycodone and 2.6 hours after the controlledrelease oxycodone ${ }^{14}$.

One of the most important benefits provided by controlled-release opioid preparations is to maintain the drug serum levels relatively constant, resulting in maintained analgesia. They also have the advantage of keeping patients free of the burden of requesting the medication when they feel pain due to reductions in serum levels of the opioid, when immediate release preparations are employed ${ }^{15}$.

When comparing the results of the frequency of adverse events, we observed the following incidences: nausea $(19.44 \%)$, vomiting (12.50\%), dizziness (4.35\%), constipation (4.35\%), pruritus (2,78\%) and insomnia $(2.78 \%)$. Franceschi et. al. researched oxycodone for treatment of pain in polytrauma patients and found $20 \%$ nausea and $26.6 \%$ constipation ${ }^{16}$. The higher frequency of constipation in that study can be explained by the time of opioid use, which was longer than in our study, limited to two days. Jokela et al. studied premedication with $15 \mathrm{mg}$ controlled-release oxycodone in gynecological laparoscopic operations and found $25 \%$ of nausea and vomiting ${ }^{17}$. The higher frequency could be explained by the different type of operation, since the gynecological laparoscopic operations may cause a higher incidence of nausea and vomiting compared with head and neck procedures. In the study by Koch et al., who used intravenous oxycodone for pain after laparoscopic cholecystectomy, the frequency of nausea was $27.7 \%$, and vomiting, $13.88 \%{ }^{18}$. The small difference between these results and those of this study could be explained by the different route of administration of oxycodone and also by the different type of surgical procedure. The higher incidence of nausea $(42.3 \%)$ and vomiting $(23.1 \%)$ found by Singla et al. ${ }^{19}$, compared with the present study, is perhaps explained by oxycodone $(5 \mathrm{mg})$ association with ibuprofen $(400 \mathrm{mg}$ ), by the fact that only women were included in the study and the type of operations (abdominal and pelvic), despite the dizziness frequency $(1.9 \%)$ and constipation (3.8\%) were quite similar. 
In this study, after treatment with controlled-release oxycodone we observed a significant decrease in the intensity of postoperative pain. The pain remained absent or mild throughout the treatment with controlled-release oxycodone. This analgesic profile coincides with that found by Ho et al. using the same dose of controlled-release oxycodone for colorectal laparoscopic operations ${ }^{20}$, by Wirz et al. in orthopedic surgery ${ }^{21}$ and by Kampe et al. in breast cancer procedures ${ }^{22}$. This research is in line with the results of Gaskell et al., who concluded that a single dose higher than $5 \mathrm{mg}$ of oxycodone is effective for the treatment of postoperative pain ${ }^{23}$. The effectiveness of oxycodone combined with paracetamol was also confirmed by Moore et al. ${ }^{24}$.

The progressive increase in the frequency of use of rescue medication observed in visits 5 and 6 could be explained by the $50 \%$ reduction in the release of controlled- release oxycodone on the second day after surgery. At visit 7 , the increased use of rescue medication can possibly be attributed to the lack of use of opioids for at least five days before the evaluation.

The rates of patient satisfaction on the overall perception of the treatment of postoperative pain found in the study by Kampe et al. ${ }^{22}$ is similar to the opinion of the investigator on the treatment used in this study.

We conclude that the controlled-release oxycodone showed a good safety and tolerability profile, with no serious adverse effects. There was a significant decrease in pain intensity and rescue medication was requested in a higher frequency when we reduced the dose of the opioid and after its suspension. The perception of the investigator about the treatment administered to the patient was excellent or good in all cases.

\title{
R E S U M O
}

\begin{abstract}
Objetivo:avaliar a segurança e a tolerabilidade da oxicodona de liberação controlada no tratamento da dor pós-operatória de ressecções oncológicas de cabeça e pescoço. Métodos:estudo prospectivo, observacional e aberto. Foram estudados 83 pacientes com dor de moderada a intensa após operações oncológicas de cabeça e pescoço. Todos receberam anestesia geral com propofol, fentanil e sevoflurano. No pós-operatório, quando apresentaram dor moderada ou intensa, foi iniciada oxicodona de liberação controlada, 20mg de 12/12 horas no primeiro dia e 10mg de 12/12 horas no segundo dia. A frequência e a intensidade de efeitos adversos, a intensidade da dor pós-operatória pela escala verbal numérica e o uso de medicação analgésica de resgate foram avaliadas de 12/12 horas após a administração do medicamento e entre 7 e 13 dias após a última dose de oxicodona. Resultados:os efeitos adversos mais frequentes foram: náusea, vômito, tontura, prurido,insônia, constipação e retenção urinária, sendo a maioria, de leve intensidade. Não ocorreram eventos adversos graves. Em menos de 12 horas após o emprego da oxicodona, ocorreu diminuição significativa da intensidade da dor pós-operatória, que permaneceu até o final do estudo. A medicação de resgate foi solicitada em uma frequência maior quando a dose do opioide foi reduzida,ou após sua suspensão. Conclusão: aoxicodona de liberação controlada demonstrou ser segura e bem tolerada e promoveu diminuição significativa da dor pós-operatória.
\end{abstract}

Descritores: Procedimentos cirúrgicos operatórios. Dor pós-operatória. Analgesia. Oxicodona. Ensaio clínico.

\section{REFERENCES}

1. Brasil. Instituto Nacional de Câncer José Alencar Gomes da Silva. Estimativa 2012: Incidência de câncer no Brasil. Rio de Janeiro: Inca; 2011

2. Staahl C, Christrup LL, Andersen SD, Arendt-Nielsen L, Drewes AM. A comparative study of oxycodone and morphine in a multimodal, tissue-diferentiateed experimental pain model. Pain. 2006;123(1-2):28-36

3. Melzack R, Katz J. Pain measurement in persons. In: Wall PD Melzack R. Editors. Textbook of pain. 3th ed. Edinburgh: Churchill Livingstone; 1994. p. 337-56.

4. Burton MB, Gebhart GF. Effects of kappa-opioid receptor agonists on responses to colorectal distension in rats with or without acute colonic inflammation. J Pharmacol Exp Ther. 1998;285(2):707-15.

5. De Schepper HU, Cremonini F, Park MI, Camilleri M. Opioids and the gut:pharmacology and current clinical experience. Neurogastroenterol Motil. 2004;16(4):383-94.

6. Kalso E. How different is oxycodone from morphine? Pain. 2007;132(3):227-8

7. Eisenach JC, Carpenter R, Curry R. Analgesia from a peripherally active kappa-opioid receptor agonist in patients with chronic pancreatitis. Pain. 2003;101(1-2):89-95.
8. Ross FB, Smith MT. The intrinsic antinociceptive effects of oxycodone appear to be kappa-opioid receptor mediated. Pain. 1997;73(2):151-7

9. Staahl C, Dimcevski G, Andersen SD, Thorsgaard N, Christrup LL, Arendt-Nielsen $\mathrm{L}$, et al. Differential effect of opioids in patients with chronic pancreatitis: an experimental pain study. Scand J Gastroenterol. 2007;42(3):383-90

10. Ma K, Jiang W, Zhou Q, Du DP. The efficacy of oxycodone for management of acute pain episodes in chronic neck pain patients. Int J Clin Pract. 2008;62(2):241-7.

11. Kokki H, Kokki M, Sjövall S. Oxycodone for the treatment of postoperative pain. Expert Opin Pharmacother. 2012;13(7):104558.

12. Pöyhiä R, Seppälä $T$, Olkkola KT, Kalso E. The pharmacokinetics and metabolism of oxycodone after intramuscular and oral administration in healthy subjects. $\mathrm{Br} J$ Clin Pharmacol. 1992;33(6):617-21.

13. Lalovic B, Kharasch E, Hoffer C, Risler L, Liu-Chen LY, Shen DD. Pharmacokinetics and pharmacodynamics of oral oxycodone in healthy human subjets: role of circulating active metabolites. Clin Pharmacol Ther. 2006;79(5):461-79.

14. Mandena JW, Kaiko RF, Oshlack B, Reder RF, Stanski DR. Charactherization and validation of a pharmacokinetic model for 
controlled-release oxycodone. Br J Clin Pharmacol. 1996;42(6):74756.

15. Cheville A, Chen A, Oster G, McGarry L, Narcessian E. A randomized trial of controlle-release oxycodone during inpatient rehabilitation following unilateral total knee arthroplasty. JBone Joint Surg Am. 2001;83-A(4):572-6. Erratum in: JBone Joint Surg Am. 2001;83$A(6): 915$

16. Franceschi F, Marini M, Ursella S, Carbone L, Candelli M, Pignataro $G$, et al. Use of oxycodone in polytrauma patients: the "Gemelli" experience. Eur Rev Med Pharmacol Sci. 2008;12(2):123-6.

17. Jokela R, Ahonen J, Valjus M, Seppälä T, Korttila K. Premedication with controlled-release oxycodone does not improve management of postoperative pain after day-case gynaecological laparoscopic surgery. Br J Anaesth. 2007;98(2):255-60.

18. Koch S, Ahlbrug P, Spangsberg N, Brock B, Tønnesen E, Nikolajsen L. Oxycodone vs. fentanyl in the treatment of early post-operative pain after laparoscopic cholecystectomy: a randomised doubleblind study. Acta Anaesthesiol Scand. 2008;52(6):845-50.

19. Singla N, Pong A, Newman K, MD-10 Study Group. Combination oxycodone $5 \mathrm{mg} / \mathrm{ibuprofen} 400 \mathrm{mg}$ for the treatment of pain after abdominal or pelvic surgery in women: a randomized, doubleblind, placebo- and active-controlled parallel-group study. Clin Ther. 2005;27(1):45-57.

20. Ho HS. Patient-controlled analgesia versus oral controlled-release oxycodone - are they interchangeable for acute postoperative pain after laparoscopic colorectal surgeries? Oncology. 2008;74 Suppl 1:61-5
21. Wirz S, Wartenberg HC, Wittmann M, Nadstawek J. Post-operative pain therapy with controlled release oxycodone or controlled release tramadol following orthopedic surgery: a prospective, randomized, double-blind investigation. Pain Clinic. 2005;17(4):36776.

22. Kampe S, Wolter K, Warm M, Dagtekin O, Shaheen S, Landwehr $S$. Clinical equivalence of controlled-release oxycodone $20 \mathrm{mg}$ and controlled-release tramadol $200 \mathrm{mg}$ after surgery for breast cancer. Pharmacology. 2009;84(5):276-81

23. Gaskell H, Derry S, Moore RA, McQuay HJ. Single dose oral oxycodone and oxycodone plus paracetamol (acetaminophen) for acute postoperative pain in adults. Cochrane Database Syst Rev. 2009;(3):CD002763.

24. Moore RA, Derry S, McQuay HJ, Wiffen PJ. Single dose oral analgesics for acute postoperative pain in adults. Cochrane Database Syst Rev. 2011;(9):CD008659.

Received 10/01/2014

Accepted for publication 06/03/2014

Conflict of interest: none.

Source of funding: Zodiac Laboratory Pharmaceuticals, through agreement with the Ary Frauzino Foundation for Research and Control of Cancer (Cancer Foundation).

\section{Mailing address:}

Ismar Lima Cavalcanti

Email: ismarcavalcanti@gmail.com 